\title{
THE SPECIES OF CANOMACULINA, MYELOCHROA, PARMELINELLA, AND PARMELINOPSIS (PARMELIACEAE, LICHENIZED ASCOMYCOTINA) FROM THE "SEGUNDO PLANALTO" IN THE STATE OF PARANÁ, BRAZIL
}

\begin{abstract}
Sionara Eliasaro ${ }^{1}$
Mónica T. Adler ${ }^{2}$

Recebido em 17/09/1999. Aceito em 11/02/2000

RESUMO-(Espécies de Canomaculina, Myelochroa, Parmelinella e Parmelinopsis (Parmeliaceae, Ascomycotina Liquenizados) do Segundo Planalto do Estado do Paraná, Brasil). Este estudo descreve as espécies de Canomaculina Elix \& Hale, Myelochroa (Asahina) Elix \& Hale, Parmelinella Elix \& Hale e Parmelinopsis Elix \& Hale ocorrentes no Segundo Planalto do Estado do Paraná. São apresentadas chaves para a identificação das espécies. Seis espécies são citadas pela primeira vez para o Estado do Paraná. Parmelinella wallichiana é citada pela primeira vez para o Continente Americano.
\end{abstract}

Palavras-chave - Parmeliaceae, Canomaculina, Myelochroa, Parmelinella, Parmelinopsis

ABSTRACT -(The species of Canomaculina, Myelochroa, Parmelinella and Parmelinopsis (Parmeliaceae, Lichenized Ascomycotina) from the "Segundo Planalto" in the State of Paraná, Brazil). The present study describes the species of Canomaculina Elix \& Hale, Myelochroa (Asahina) Elix \& Hale, Parmelinella Elix \& Hale and Parmelinopsis Elix \& Hale occuring in the "Segundo Planalto" in the State of Paraná. Keys Identification are given. Six species are reported for the first time for Paraná. Parmelinella wallichiana is cited for the first time for the American continent.

Key words - Parmeliaceae, Canomaculina, Myelochroa, Parmelinella, Parmelinopsis

\section{Introduction}

The present work is part of an intensive survey of the Parmeliaceae sensu stricto of the "Segundo Planalto" of the state of Paraná, South Brazil. The studied area is delimited by the following latitudes and longitudes: $24^{\circ} 30^{\prime}$ $26^{\circ} 06^{\prime} \mathrm{S}$ and $50^{\circ} 25^{\prime}-49^{\circ} 49^{\prime} \mathrm{W}$. Its climate is characterized as subtropical-temperate, with some nocturnal frosts in the winter, a mean annual precipitation of $1423 \mathrm{~mm}$, and a mean annual temperature of $17.6^{\circ} \mathrm{C}$ (Maack 1981).

The lichen flora of Paraná has not yet been systematically surveyed so far the scanty extant information about the Parmeliaceae being scattered in different publications (Hale 1976a, 1976b; Kurokawa 1974, 1985; Osorio 1973, 1977a, 1977b; Fleig 1997; Eliasaro \& Adler 1997, 1998; Eliasaro et al. 1998).

1 Departamento de Botânica, Universidade Federal do Paraná, C. Postal 19031, CEP 81531-970, Curitiba, PR, Brasil

2 Departamento de Ciencias Biológicas, Facultad de Ciencias Exactas y Naturales, Universidad de Buenos Aires, 1428 , Buenos Aires, Argentina 
The group of genera designated by Elix (1993) as Parmelia sensu lato are herein named Parmeliaceae sensu stricto. They are represented in most ecosystems and display a great variety of secondary metabolites produced by the fungal component (mostly aliphatic acids, depsides, depsidones, dibenzofurans, anthraquinones and xanthones), which are commonly used in taxonomy and have potential pharmaceutical applications.

The genera Canomaculina Elix \& Hale, Myelochroa Elix \& Hale, Parmelinella Elix \& Hale and Parmelinopsis Elix \& Hale were segregated from Parmelina Hale (Elix \& Hale 1987), and comprise a group of taxa with atranorin in the upper cortex and with relatively narrow, marginally ciliate, adnate lobes.

The species of Canomaculina, Myelochroa, Parmelinella and Parmelinopsis, which occur on the "Segundo Planalto" of the State of Paraná, are herein briefly described.

\section{Material and methods}

The specimens studied were mostly collected by the first author and are housed at UPCB (see Holmgren et al. 1990 for herbarium acronyms). Sampling was mainly done at the following selected localities: Jaguariaíva (Parque Estadual do Cerrado); Tibagí (Guartelá); Ponta Grossa (Parque Estadual de Vila Velha and Buraco do Padre); and Lapa (Parque Estadual Gruta do Monge and surroundings).

Type specimens studied are housed at G, TUR, and W. Reference material kept at both $\mathrm{BAFC}$ and US were also examined.

Herbarium specimens were examined with a dissecting microscope for morphological characterization; ascospores and conidia were measured after mounting in $10 \% \mathrm{KOH}$ plus $1 \%$ phloxine.

Spot tests on the upper cortex and medulla were carried out with reagents $\mathrm{K}(10 \% \mathrm{KOH})$, C (30\% Potassium hypochlorite) and $\mathrm{K}$, followed by $\mathrm{C}(\mathrm{KC})$.

Lichen substances were identified by thin layer chromatography (Culberson \& Ammann 1979; Elix et al. 1988), and by comparison with authentic samples.

\section{Results and discussion}

Canomaculina Elix \& Hale, Mycotaxon 29: 239. 1987.

This genus is characterized by tapered (simple to furcate) cilia, effigurate-maculate upper surface of the lobes, filiform conidia, and simple to furcately branched rhizines (Elix 1993). Recently, Elix (1997) extended the concept of Canomaculina, including all species formerly belonging to Rimeliella Kurok. Nevertheless, we prefer to treat both genera separately until the criteria of delimitation are settled. Therefore, only two species of Canomaculina s. str. are described for the studied area.

\section{Key to the species of Canomaculina}

1. Thallus lacking vegetative propagules, medulla $\mathrm{K}$ C. consors

1. Thallus sorediate-pustulate, medulla $\mathrm{K}+$ yellow, turning orange C. muelleri

Canomaculina consors (Nyl.) Elix \& Hale, Mycotaxon 29: 239. 1987.

Parmelia consors Nyl., Flora, Jena 68: 613. 1885.

Thallus corticolous, adnate, greenish-grey, $4-13 \mathrm{~cm}$ across. Lobes subirregular, apically rounded, margins crenate, densely ciliate; cilia robust, up to $1 \mathrm{~mm}$ long, simple or commonly furcate. Upper surface with white, effigurate macules, sometimes pruinose at the apices, lacking vegetative propagules. Medulla white. Lower surface black, rhizinate to towards the margin or with a bare brown marginal zone, moderately rhizinate; rhizines of two types, either thick and up to $5 \mathrm{~mm}$ long, or thin, less than $1 \mathrm{~mm}$ long, intermixed, simple, furcate or rarely squarrosely branched. Apothecia substipitate, 2-10mm diam., disc brown, 
imperforate or perforate. Ascospores ellipsoid to subglobose, $14-16 \times 8-10 \mu \mathrm{m}$. Pycnidia not found.

Chemistry: Upper cortex $\mathrm{K}+$ yellow (atranorin, major). Medulla K-, C-, KC(unidentified aliphatic acids, minor).

Specimens examined: BRAZIL. Paraná: Tibagí, Guartelar, 17/IV/1994, Eliasaro 1305 (UPCB); Lapa, near Parque Estadual Gruta do Monge, 9/X/1996, Eliasaro 1929(UPCB).

This South American and Australian species (Hale 1976a; Elix 1994) is characterized by the absence of vegetative propagules and the negative results for medullary tests (presence of aliphatic acids or no substances demonstrated). Rare at the "Segundo Planalto", it occurs on trees in the cerrado or along roads. It was formerly reported by Hale (1976a) from the Brazilian states of Mato Grosso, Minas Gerais, Rio de Janeiro, Rio Grande do Sul, Santa Catarina, São Paulo, and recorded further by Osorio (1977b) from Paraná.

Canomaculina muelleri (Vain.) Elix \& Hale, Mycotaxon 29: 240. 1987.

Parmelia muelleri Vain., Acta Soc. Fauna Fl. Fenn. 7: 49. 1890.

Thallus corticolous, adnate, greenish-grey, $5-10 \mathrm{~cm}$ across. Lobes subirregular, apically rounded, $5-10 \mathrm{~mm}$ wide, densely ciliate, cilia commonly robust, tapered, up to $1 \mathrm{~mm}$ long, simple or commonly furcate. Upper surface white, effigurate-maculate, sometimes pruinose at the apices, submarginally sorediate; soralia at first punctiform, then orbicular, sometimes confluent at maturity. Medulla white. Lower surface black, moderate to densely rhizinate to towards the margins, or with a brown, bare or papillate marginal zone under the lobe apices; rhizines black, of two types, either thick and up to $5 \mathrm{~mm}$ long or thin and less than $1 \mathrm{~mm}$ long, simple, furcate or rarely squarrosely branched. Apothecia sessile, 1-2mm diam.; amphithecium sorediate, disc brown, imperforate. Ascospores hyaline, ellipsoid to subglobose, 12-13 x $8 \mu \mathrm{m}$.
Pycnidia not seen.

Chemistry: Upper cortex $\mathrm{K}+$ yellow (atranorin, major). Medulla $\mathrm{K}+$ yellow, C-, KC(stictic acid, major).

Specimens examined: BRAZIL. Paraná: Ponta Grossa, Parque Estadual de Vila Velha, 8/IV/1996, Eliasaro 1856, 1859 (UPCB); Tibagí, Guartelá, 17/IV/1994, Eliasaro 1306(UPCB).

This species is characterized by the sorediate upper cortex and stictic acid as the major component in the medulla. It is morphologically similar to $C$. pilosa Stizenb., a common species in Curitiba, and differs only in the medullary chemistry (aliphatic acids in $C$. pilosa). C. muelleri was reported by Hale (1976a) from Mexico, Venezuela, Peru, Argentina, and Brazil (Minas Gerais), and further recorded for Paraná State (Osorio 1977a) and Uruguay (Osorio 1980).

Myelochroa (Asahina) Elix \& Hale, Mycotaxon 29: 240. 1987.

This genus is mainly characterized by thalli with narrow, grey lobes, simple cilia, simple to squarrosely branched rhizines, and a yellow to orange medulla, containing secalonic acid derivates and hopane triterpenes (Elix 1993). It is represented by one species in the studied area.

Myelochroa lindmanü (Lynge) Elix \& Hale, Mycotaxon 29: 241. 1987.

Parmelia lindmanii Lynge, Arkiv Bot. 13: 74. 1914.

Thallus corticolous, adnate, greenish-grey, $4-10 \mathrm{~cm}$ across. Lobes subirregular, apically rounded to subtruncate, $5-8 \mathrm{~mm}$ wide, cilia restricted to the lobe axils, simple, less than $0.5 \mathrm{~mm}$. Upper surface flat, shiny, moderately to densely isidiate; isidia simple, cylindrical. Medulla sulfur-yellow. Lower surface black, with a brown marginal zone, moderately rhizinate; rhizines black, simple. Apothecia sessile, 2-6mm diam.; amphithecium isidiate, disc brown, imperforate. Ascospores hyaline, 8$12 \times 6-8 \mu \mathrm{m}$. Pycnidia immersed. Conidia 
bifusiform 6-7 $\mu \mathrm{m}$.

Chemistry: Upper cortex $\mathrm{K}+$ yellow (atranorin, major). Medulla $\mathrm{K}-, \mathrm{C}-$, $\mathrm{KC}$ (secalonic acids, major).

Specimens examined: BRAZIL. Paraná: Jaguariaíva, Parque Estadual do Cerrado, 16/IV/ 1994, Eliasaro 1264c (UPCB); 19/IV/1995, Eliasaro 1369(UPCB); Tibagí, Guartelar, 22/I/ 1996, Eliasaro 1492 (UPCB); Ponta Grossa, Parque Estadual de Vila Velha, 27/III/1996, Eliasaro 1783 (UPCB).

This species was reported by Hale (1976a) from Mexico and South America (Colombia, Venezuela, Paraguay, Uruguay, Argentina and Brazil: Rio Grande do Sul). It was also cited for Paraná, Mato Grosso do Sul (Osorio 1977a), and Minas Gerais (Ribeiro 1998).

Parmelinella Elix \& Hale, Mycotaxon 29: 241. 1987.

Elix (1993) characterized this genus mainly by the thalli with moderately broad grey lobes, simple cilia and rhizines, a yellow-grey upper cortex, containing traces of secalonic acids and atranorin, ascospores $15-18 \times 8-10 \mu \mathrm{m}$, and cylindrical conidia being $5-9 \mu \mathrm{m}$ long. Our measurements of spore dimensions are more or less coincident with the above range for $P$. wallichiana but not for $P$. versiformis, which has larger spores, commonly with thick episporium. Our observations on collected specimens and type material of $P$. versiformis and $P$. wallichiana show that both have bifusiform to sublageniform conidia being (5-) 6.5-7 $\mu \mathrm{m}$ long. Therefore it is necessary to redefine both ascospore dimensions and the type of conidia found in the genus Parmelinella.

In addition, traces of secalonic acids in the upper cortex are probably not an important taxonomic character of the genus, as indicated by the results of the HPLC analysis of two samples of Parmelinella from Curitiba, which are commented on below.

This genus is represented by two species in the studied area.

Key to the species of Parmelinella

1. Thallus lacking vegetative propagules

1. Thallus isidiate $P$. ventiformis P. wallichiana

Parmelinella versiformis (Kremp.) Marcelli, Acta bot. bras. 7: 56. 1993.

Parmelia versiformis Kremp., Flora 61: 464. 1878. Type collection: Argentina, Lorentz \& Hieronymus (lectotype by Hale, G!).

Parmelia mutata Vain., Acta Soc. Fauna Fl. Fenn. 7(7): 39. Type collection: Brazil, Minas Gerais, Sítio (Antonio Carlos), Vainio: Lichenes Brasilienses Exsiccati. 1891 (lectotype by Hale, TUR!).

Parmelia catharinensis Müll. Arg., Flora $74: 239.1891$. Type collection: Brazil, near Santa Catarina, Ule 73 (isolectotype by Hale, W!).

Parmelia wettsteinii Zahlbr. Denkschr. Akad. Wiss. Wien., Math.-Naturwiss. Klasse 83: 173. 1909. Type collection: Brazil, São Paulo, near Taipas, Schiffiner \& Wettstein (lectotype by Hale, W!).

Thallus corticolous, adnate, pale buff to greenish-grey, 3-5cm across. Lobes subirregular, apically roundish, crenate, $5-8 \mathrm{~mm}$ wide; cilia sparse, mostly in lobe axil, simple, less than $0.5 \mathrm{~mm}$. Upper surface flat, soredia and isidia lacking. Medulla white. Lower surface dark brown to blackening, with a brown bare or papillate marginal zone, or medium to pale brown or beige (paler marginally), moderately rhizinate; rhizines simple, concolorous or whitish when young, sometimes dark brown contrasting with a pale lower surface. Apothecia frequent, sessile, 2-5mm diam., disc brown, imperforate. Ascospores (16-)21-26(-29) x (10-) $12-15 \mu \mathrm{m}$, commonly with episporium (1.5-)2-3(-4) $\mu \mathrm{m}$ thick. Pycnidia frequent, laminal, immersed. Conidia bifusiform to sublageniform, 6-7 $\mu \mathrm{m}$ long.

Chemistry: Upper cortex $\mathrm{K}+$ yellow 
(atranorin, major). Medulla $\mathrm{K}+$ yellow turning red (salazinic acid, major).

Selected specimens examined: BRAZIL. Paraná: Lapa, 6/II/1996, trees along road, on thin branches, Eliasaro 1753(UPCB); Curitiba: Centro Politécnico, 15/IX/1993, Eliasaro 1084 (UPCB, BAFC, CANB), 13/IV/1998, Eliasaro (UPCB).

This South American species has been reported by Hale (1976a) from Argentina and Brazil: Minas Gerais, São Paulo, Santa Catarina and Rio de Janeiro. These are the first records for the State of Paraná.

The specimens of $P$. versiformis collected in the studied area grow mostly on small branches and are commonly small, with a dark (brown to blackening) lower surface, while the specimens collected in Curitiba are quite well developed and may be assigned to two types: a) those with a darker lower surface (medium brown to black, particularly at the centre), mostly collected on tree branches, and b) those with a paler lower surface (medium to pale brown), collected mostly on tree trunks. The type collection of Parmelia versiformis Kremp. corresponds to the second type (b), whereas the other three type specimens (of $P$. mutata Vain., $P$. catharinensis Müll. Arg. and P. wettsteinil Zahlbr.) have a black lower surface like those of type (a).

Parmelinella wallichiana (Taylor) Elix \& Hale, Mycotaxon 29: 242. 1987.

Parmelia wallichiana Taylor, Hooker J. Bot. 6: 176.1847.

Parmelia nimandairana Zahlbr., Fedde Repert. 33: 55. 1934. Type collection: Taiwan, Nimandaira, Mt. Arisan, 24/XII/1925, Asahina 63 (lectotype by Hale, W!).

Thallus corticolous, adnate, $3-5 \mathrm{~cm}$ across. Lobes subirregular, apically rounded, crenate, $5-8 \mathrm{~mm}$ wide, cilia in lobe axils, simple, less than $0.5 \mathrm{~mm}$. Upper surface plane, moderately to densely isidiate; isidia simple, cylindrical, rarely branched. Medulla white. Lower surface black to medium brown or medium brown to pale brown, with a brown, papillate marginal zone, moderately rhizinate; rhizines simple, concolorous or whitish, sometimes dark brown in contrast with the pale brown lower surface. Apothecia sessile, rare, 2-3mm diam., amphithecium isidiate, disc brown, imperforate. Ascospores 14-18(23)x(8-)10-11(-16) $\mu \mathrm{m}$. Pycnidia very rare. Conidia bifusiform to sublageniform, 5-7 $\mu \mathrm{m}$ long.

Chemistry: Upper cortex $\mathrm{K}+$ yellow (atranorin, major). Medulla $\mathrm{K}+$ yellow turning red, C-, KC- (salazinic acid, major).

Selected specimens examined: BRAZIL. Paraná: Lapa, 6/II/1996, trees along road, Eliasaro 1688, 1705 (UPCB); 9/X/96, Eliasaro 1874, 1921 (UPCB); Curitiba, Parque Bacacheri, 8/IX/1998, Eliasaro 2102 (UPCB); Parque Iguaçu, Jardim Zoológico, 16/XII/1998, Eliasaro \& Donha 278, 280 (UPCB); Centro Politécnico, 15/III/1993, Eliasaro 1085(UPCB); 1/II/1994, Eliasaro 1165, 1166 (UPCB); 20/V/1994, Morales 62 (UPCB); 2/X/1995, Bündchen 122 (UPCB); 25/VI/1998, Eliasaro 1997 (UPCB); Centro Cívico, 15/XI/1998, Donha 174, 182b (UPCB).

This species was reported for eastern Africa, India, Southeastern Asia, Japan, and Australia (Hale 1976a; Elix 1994). The present is the first report for the American continent.

This species was collected in the "Segundo Planalto" and in the city of Curitiba. The specimens can also be assigned to two types (particularly as regards the colour of the lower side) as in P. versiformis, and are also better developed in Curitiba.

The pattern of colour variation of the lower surface follows the same as described for $P$. versiformis: dark lower surface in the "Segundo Planalto" specimens (similar to those collected on tree branches in Curitiba), and pale lower surface in the specimens collected on tree trunks in Curitiba. $P$. wallichiana is very probably the isidiate counterpart of $P$. versiformis, and as expected for the presence of vegetative 
propagules, is a very widespread species.

The chemical analysis by HPLC of one sample from $P$. versiformis of Curitiba (duplicate of $S$. Eliasaro 1084) and one sample of $P$. wallichiana (duplicate of $S$. Eliasaro 1085), by Dr. Isao Yoshimura, revealed the abscence of traces of secalonic acids. This suggests that the presence of traces of secalonic acids is not a determinant taxonomic character for the genus Parmelinella.

Parmelinopsis Elix \& Hale, Mycotaxon 29: 242. 1987.

This genus is mainly characterized by thalli with narrow, apically truncate, grey lobes, relatively large spores, cylindrical conidia, simple cilia and simple to sparsely branched rhizines (Elix 1993).

It is represented by five species in the "Segundo Planalto".

Key to the species of Parmelinopsis

1. Thallus lacking vegetative propagules

1. Thallus with vegetative propagules

2. Thallus with nonsorediate pustules

P. spumosa

2. Thallus isidiate or lobulate

3. Thallus densely lobulate

P. schindleri

3. Thallus isidiate

4. Isidia ciliate P. horrescens

4. Isidia eciliate P. minarum

Parmelinopsis damaziana (Zahlbr.) Elix \& Hale, Mycotaxon 29: 242. 1987.

Parmelia damaziana Zahlbr., Bull. Herb. Boiss. 5: 541. 1905. Type collection: Brazil, Minas Gerais: Monte Itacolomi (Ouro Preto), Damazio 1375 (lectotype by Hale, W!).

Parmelia brachyconidia Zahlbr. Bull. l'Herbier Boissier, ser. 2, 5: 465. 1908. Type collection: Brazil, Minas Gerais: Serra de Ouro Preto, Damazio 1741 (lectotype by Hale, W!).

Thallus corticolous or saxicolous, adnate, whitish grey, $3-6 \mathrm{~cm}$ across. Lobes sublinear to subirregular, $0.8-3 \mathrm{~mm}$ wide, ciliate; cilia scattered, mainly simple, rarely furcate. Medulla white. Lower surface black, moderately rhizinate; rhizines black, mainly simple, sometimes furcate or squarrose. Apothecia common, sessile, 8-12mm diam., amphithecium smooth. Ascospores (13-)16-18x(6.5-)8-12 $\mu \mathrm{m}$.

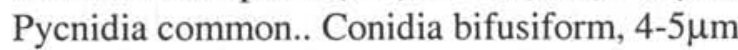
long.

Chemistry: Cortex $\mathrm{K}+$ yellow (atranorin, major); medula $\mathrm{K}-, \mathrm{C}$ - or $\mathrm{C}+$ pink, $\mathrm{KC}+$ pink (3-methoxy-2,4-di-O-methylgyrophoric acid (= horrescens unknown), major; gyrophoric acid, major to minor; 5-O-methylgyrophoric acid, major; hiascic acid, minor to absent; 4-5-di-Omethylhiascic, minor).

Specimens examined: BRAZIL. Paraná: Ponta Grossa, Parque Estadual de Vila Velha, 27/I/1996, Eliasaro 1584(UPCB): Lapa, Parque Estadual Gruta do Monge, 6/II/1996, Eliasaro 1718, 1720, 1757 (UPCB); 9/X/1996, Eliasaro 1876 (UPCB).

This quite rare species has been reported by Hale (1976a) from Brazil: Minas Gerais and Rio de Janeiro, and from São Paulo (Ribeiro 1998). It was also recorded for East Africa by Krog and Swinscow (1979), and Swinscow and Krog (1988). It is here cited for the first time for the state of Paraná and constitutes the southernmost record for this species.

Parmelinopsis horrescens (Taylor) Elix \& Hale, Mycotaxon 29: 242. 1987.

Parmelia horrescens Taylor, Flora Hibern.: 144. 1836.

Thallus adnate, corticolous, whitish grey, up to $7 \mathrm{~cm}$ across. Lobes sublinear to subirregular, subdichotomously branched, 0.8$1.5 \mathrm{~mm}$ wide, moderately to densely ciliate; cilia simple, rarely furcate; densely isidiate. Isidia cylindrical, simple or branched, frequently with apical cilia. Medulla white. Lower surface black, moderately rhizinate; rhizines black, mainly simple, sometimes furcate or squarrose. 
Apothecia and pycnidia not found. (Ascospores 16-18x10-12 $\mu \mathrm{m}$ according to Krog \& Swinscow 1988).

Chemistry: Cortex $\mathrm{K}+$ yellow (atranorin); medula $\mathrm{C}+$ pink, $\mathrm{KC}+$ pink (3-methoxy-2,4-di$\mathrm{O}$-methylgyrophoric acid (= horrescens unknown), major; 5-O-methylhiascic acid, minor; gyrophoric acid, major; umbilicaric acid, major; 3- methoxyhiascic acid, minor to absent).

Specimens examined: BRAZIL. Paraná: Jaguariaíva, Parque Estadual do Cerrado, 19/IV/1995, Eliasaro 1363(UPCB); Ponta Grossa, Parque Estadual de Vila Velha, 27/IX/1995, Eliasaro (UPCB).

This species is distributed worldwide in temperate regions and at higher altitudes in the tropics (Swinscow \& Krog 1988). It was reported for East Africa by Swinscow \& Krog (1988). Hale (1976a) also cited it for South Africa, Asia (India, Java, Philippines, Taiwan, Japan), Europe (Ireland, Spain and France), USA, Mexico, Central America and the Antillas, South America (Venezuela and Uruguay), Australia and New Zealand.

In Brazil it was formerly reported for the states of São Paulo (Pereira \& Marcelli 1989), Goiás and Minas Gerais (Marcelli 1993).

Parmelinopsis minarum (Vainio) Elix \& Hale, Mycotaxon 29: 243. 1987.

Parmelia minarum Vainio, Acta Soc. Fauna Flora fenn. 7: 48. 1890. Type collection: Brazil, Minas Gerais, Sítio, 1885, Vainio, Lich. Brasil. Exs.

Thallus corticolous or saxicolous, adnate, greenish grey, $3-4 \mathrm{~mm}$ wide. Lobes sublinear, subdichothomously branched, often imbricate, $0.5-2 \mathrm{~mm}$; cilia evenly dispersed, simple, densely isidiate; isidia cylindrical, simple to branched, commonly darkening at the apex, eciliate. Lower surface black, moderately rhizinate; rhizines black, mainly simple, sometimes furcate or squarrose. Apothecia rare, 2-3mm diam., sessile, amphithecium isidiate, disc brown. Ascospores $14-16 \times 7-8 \mu \mathrm{m}$. Pycnidia not found.
Chemistry: Cortex $\mathrm{K}+$ yellow (atranorin, major); medulla $\mathrm{C}+, \mathrm{KC}+$ pink (3-methoxy-2,4di-O-methyl-gyrophoric acid (horrescens unknown), minor to absent; 5-O-methylhiascic, major; gyrophoric acid, major; hiascic acid, major.

Specimens examined: BRAZIL. Paraná: Tibagí, Guartelá, 20/IX/1993, Eliasaro 1105 (UPCB); 22/I/1996, Eliasaro 1516 (UPCB); Ponta Grossa, Parque Estadual de Vila Velha, 8/IV/1996, Eliasaro 1768, 1781, 1793 (UPCB); Lapa, beira de estrada, 6/II/1996, Eliasaro 1709, 1712 (UPCB), Parque Estadual Gruta do Monge, 9/IX/1996, Eliasaro 1942b(UPCB).

This cosmopolitan species is known from all continents except Antarctica (Elix 1994). Hale (1976a) treated Parmelia minarum Vain. as a taxonomic synonym of Parmelia dissecta Nyl. (=Parmelina dissecta (Nyl.) Hale) recording Brazilian localities for $P$. dissecta (States of Paraná and Minas Gerais). This latter name regarded is a synonym of Parmelinopsis horrescens (Elix 1994c), who considers that "Parmelia dissecta has been misapplied for many years and most reports refer to Parmelinopsis minarum". Therefore, carefull revision is necessary to apply the correct Brazilian distribution of $P$. minarum. The species has also been reported by Osorio et al. (1980) from Rio Grande do Sul, and by Marcelli (1993) from São Paulo.

Parmelinopsis schindleri (Hale) Elix \& Hale, Mycotaxon 29: 243. 1987.

Parmelina schindleri Hale, Smithsonian Contrib. Bot. 33: 44. 1976.

Thallus adnate, corticolous, $3-8 \mathrm{~cm}$ wide. Lobes sublinear, $0.3-0.5 \mathrm{~mm}$ wide; cilia mostly at the lobe axils, simple, densely lobulate; lobules at margin lobes or at the upper surface, suberect or procumbent, ciliate. Lower surface black, moderately rhizinate; rhizines black, mainly simple to furcate or squarose. Apothecia rare, disc brown, 2-5 mm diam., sessile, margin crenate to lobulate. Ascospores 
15-18 x 8-10 $\mu \mathrm{m}$. Pycnidia not found.

Chemistry: Cortex $\mathrm{K}+$ yellow (atranorin, minor); medula C-, $\mathrm{KC}+$ rose (3-methoxy-2,4di-O-methylgyrophoric acid (= horrescens unknown), minor; 5-O-methyl hiascic acid, minor; gyrophoric acid, minor; umbilicaric acid, minor).

Specimens examined: BRAZIL. Paraná: Ponta Grossa, Parque Estadual de Vila Velha, 27/IX/1995, Bündchen 86 (UPCB), Eliasaro 1450(UPCB); 8/X/1996, Eliasaro 1808, 1825 , 1830,1854 (UPCB); Lapa, Parque Estadual Gruta do Monge, 9/X/1996, Eliasaro 1883 (UPCB). Rio de Janeiro: Rio de Janeiro, Schindler 5347(US).

This species is only known from Brazil and was reported for the states of Minas Gerais, Rio de Janeiro (Hale 1976a) and São Paulo (Ribeiro 1998). This is the first report for the state of Paraná.

Parmelinopsis spumosa (Asahina) Elix \& Hale, Mycotaxon 29: 243. 1987.

Parmelia spumosa Asahina, J. Jap. Bot. 26: 259. 1951.

Thallus corticolous, adnate, greenish grey, $2-3 \mathrm{~cm}$ wide. Lobes sublinear, $0.5-2 \mathrm{~mm}$; cilia evenly dispersed; simple; with closed pustules or bursting open, but not sorediate. Medulla pale yellow at pustules. Lower surface black, moderately rhizinate; rhizines black, mainly simple. Apothecia and pycnidia not seen.

Chemistry: Cortex $\mathrm{K}+$ yellow (atranorin, major); medula $\mathrm{K}-, \mathrm{C}+$ pink, $\mathrm{KC}+$ pink (2-4,5tri-O-methylhiascic acid, major to minor; gyrophoric acid, major; and an unidentified pigment).

Specimens examined: BRAZIL. Paraná: Tibagí, Guartelá, 22/I/1996, Eliasaro 1488 (UPCB); Lapa, Parque Estadual Gruta do Monge, 9/X/1996, Eliasaro 1890, $1930 b$ (UPCB); on trees along roads, 6/II/1996, Eliasaro 1703(UPCB).

In Brazil this taxon was formerly reported for São Paulo (Hale 1976a), Santa Catarina, Rio de Janeiro (Marcelli 1987), Mato Grosso (Marcelli 1993), and Minas Gerais (Ribeiro
1998). These are the first reports for Paraná State.

\section{Acknowledgements}

The authors thank to the Curators of the herbaria G, TUR, US and W for the loan of collections, and to Dr. Isao Yoshimura for the HPLC analysis of two samples of Parmelinella. This research was made possible by the support of the Consejo Nacional de Investigaciones Científicas y Técnicas (CONICET, Argentina) through the PIP 4492/96-99 and the PRHIDEB (publication number of this paper: 180) and for funding M. T. Adler as a "Miembro de la Carrera del Investigador del CONICET". We also thank the Universidad de Buenos Aires for financial assistance through the grants UBACYT EX047 and EXT59.

\section{References}

Culberson, C. F. \& Ammann, K. 1979. Standarmethode zur Dünnschicht-chromatographie von Flechtensubstanzen. Herzogia 5: 1-24.

Eliasaro, S. \& Adler, M. T. 1997. Two new species and new reports in the Parmeliaceae sensu stricto (Lichenized Ascomycotina) from Brazil. Mycotaxon 63: 49-55.

Eliasaro, S. \& Adler, M. T. 1998. Rimelia pontagrossensis, a new species in the Parmeliaceae sensu stricto (Lichenized Ascomycotina) from Brazil. Mycotaxon 66: 127-130.

Eliasaro, S.; Adler, M. T. \& Elix, J. A. 1998. The species of Hypotrachyna (Parmeliaceae, Lichenized Ascomycotina) from the "Segundo Planalto" in the state of Paraná, Brazil. Mycotaxon 69: 225-270.

Elix, J. A. 1993. Progress in the generic delimitation of Parmelia sensu lato lichens (Ascomycotina: Parmeliaceae) and a synoptic key to the Parmeliaceae. Bryologist 96: 359-383.

Elix, J. A. 1994. Lichens - Lecanorales 2, Parmeliacae. Flora of Australia 55: 1-360.

Elix, J. A. 1997. The lichen genera Canomaculina and Rimeliella (Ascomycotina, Parmeliaceae). Mycotaxon 65: 475-479.

Elix, J. A. \& Hale, M. E. 1987. Canomaculina, Myelochroa, Parmelinella, Parmelinopsis and Parmotremopsis, five new genera in the Parmeliacae (Lichenized Ascomycotina). Mycotaxon 24: 233-244. 
Elix, J. A.; Johnston, J. \& Parker, J. L. 1988. A computer program for the rapid identification of lichen products. Mycotaxon 31: 89-99.

Fleig, M. 1997. Os gêneros Parmotrema, Rimelia e Rimeliella (Lichenes-Ascomycotina, Parmeliaceae) no Rio Grande do Sul, Brasil. $\mathrm{PhD}$ thesis, Universidade de São Paulo, São Paulo.

Hale, M. E. 1976a. A monograph of the lichen genus Parmelina Hale (Parmeliaceae). Smithsonian Contributions to Botany 33: 1-60.

Hale, M. E. 1976b. A monograph of the lichen genus Pseudoparmelia Lynge (Parmeliaceae). Smithsonian Contributions to Botany 31: 1-62.

Holmgren, P. K.: Holmgren, N. H. \& Barnett, L. C. 1990. Index Herbariorum. 8th Part I: The herbaria of the world. Regnum Vegetabile 120: 1-693.

Krog, H. \& Swinscow, T. D. V. 1979. Parmelia subgenus Hypotrachyna in East Africa. Norwegian Journal of Botany 26: 11-43.

Kurokawa, S. 1974. Four new species of Parmelia from Brazil. Bulletin of the National Science Museum 17: 297-301.

Kurokawa, S. 1985. Parmelia diffractaica (Parmeliaceae, Lichenes) new to Brazil. Journal of Japanese Botany 60: 47-48.

Maack, R. 1981. Geografia física do Estado do Paraná. 2 ed., José. Olimpio, Rio de Janeiro.

Marcelli, M. P. 1987. Ecologia dos liquens da região sul-sudeste do Brasil, com especial atenção aos de Itanhaém (SP). PhD thesis, Universidade de São Paulo, São Paulo.
Marcelli, M. P. 1993. Pequenas Parmelia s.l. (Líquens: Ascomycotina) ciliadas dos cerrados brasileiros. Acta Botanica Brasilica 7(2): 25-70.

Osorio, H. 1973. Contribution to the lichen flora of Brazil I. New or additional records. Revista da Faculdade de Ciências de Lisboa 17(2): 447-450.

Osorio, H. 1977a. Contribution to the lichen flora of Brazil II. Lichenes from Guarapava, Paraná State. Dusenia 10: 101-102.

Osorio, H. 1977b. Contribution to the lichen flora of Brazil III. Lichenes from Western Paraná. Acta Biologica Paranaense 6: 3-7.

Osorio, H. 1980. Contribution to the lichen flora of Uruguay XIV. New and additional records from central Uruguay. Mycotaxon 11: 250-254.

Osorin, H.; Aguiar. L. W. \& Zanette, V. C. 1980. Contribution to the lichen flora of Brazil VII New or additional records from Rio Grande do Sul State. The Bryologist 84: 79-81.

Pereira, W. R. \& Marcelli, M. P. 1989. Líquens da Reserva Biológica do Alto da Serra de Paranapiacaba. Acta Botanica Brasilica 3(2): 89-94.

Ribeiro, C. H. 1998. A família Parmeliaceae (Ascomycota liquenizados) em regiões montanhosas dos Estados de Minas Gerais, Rio de Janeiro e São Paulo. M.Sc. dissertation. Universidade de São Paulo, São Paulo.

Swinscow, T. D. V. \& Krog, H. 1988. Macrolichens of East Africa. British Museum, London. 